\title{
Assessment of Haematological and Biochemical Changes in Postpartum Anoestrous Ongole Cattle of Andhra Pradesh
}

\author{
M. Rama Goury ${ }^{1}$, B.V.S. Saikiran², S.K.I. Vasantha ${ }^{2} *$, \\ Nikhil Kumar Tej ${ }^{2}$ and C.H. Srinivasa Prasad ${ }^{2}$ \\ ${ }^{1}$ NTR College of Veterinary Science, Gannavaram, A.P, India \\ ${ }^{2}$ Dept of Veterinary Physiology, NTR College of Veterinary Science, Gannavaram, A.P, India \\ *Corresponding author
}

\section{A B S T R A C T}

\begin{tabular}{l} 
Ke y w or d s \\
Hematology, \\
Biochemical, \\
$\begin{array}{l}\text { Postpartum } \\
\text { anoestrous (PPA); } \\
\text { Ongole cattle }\end{array}$ \\
\hline Article Info \\
$\begin{array}{l}\text { Accepted: } \\
\text { 12 December } 2020 \\
\text { Available Online: } \\
\text { 10 January } 2021\end{array}$ \\
\hline
\end{tabular}

The present study was aimed to assess the hemato-biochemical changes in postpartum anoestrous Ongole cattle. A total of 12 animals of same age and body weight were randomly selected and divided in to two groups, G I: postpartum anoestrous (PPA, $n=6$ ) and G II: cyclic animals $(n=6)$. Blood samples were collected by jugular vein puncture and analyzed for hematological parameters. Further, the serum was separated from another aliquot of blood sample and utilized for biochemical parameters. The mean $\mathrm{RBC}, \mathrm{Hb}, \mathrm{PCV}$, glucose, total protein and cholesterol values were significantly $(\mathrm{p}<0.05)$ lower in PPA compared to cyclic animals. In contrast, no significant ( $\mathrm{p}>0.05$ ) difference was observed in $\mathrm{MCV}, \mathrm{MCH}$, MCHC, WBC, lymphocyte and monocytes between groups. From the present study, it was concluded that hematological and biochemical parameters are reliable indicators of postpartum anestrus.

\section{Introduction}

The state of Andhra Pradesh is well known for the famous Ongole breed of cattle across the world. Interest of cattle breeding especially of Ongole breed has tremendously increased in world especially in India due to the fundamental role played by them in much climatically disadvantaged agricultural system
(Kumar et al., 2015). However there are certain reproductive impediments that are limiting the future prospects of the breed (Malik et al., 2011). Among the various factors reducing the reproductive efficiency, postpartum anestrous (PPA) is a vital anomaly. Many factors contributing individually or in concert were recognized to be responsible for postpartum infertility and 
anestrous making it a complex phenomenon. These factors include

mineral deficiencies, nutrients (khan et al., 2014), Feed quality, infection (Nishi et al., 2018), season (Perera et al., 2011), body condition, suckling (Montiel and Ahuja, 2005), and parity (Pouilly et al., 1994), etc. There were reports of high incidence of anestrous associated with deficiencies of cholesterol (Kumar et al., 1991) glucose (Jani et al., 1995) and total protein (Arosh et al., 1998 ) etc. Haematological profiles also play a key role in diagnosis of certain reproductive disorders. Lower haemoglobin $(\mathrm{Hb})$ levels might influence the tissue oxygenation of reproductive tract and there by affect the cyclicity of the animal (Kumar et al., 1991). On this background we hypothesize that the physiological status varies with reproductive efficiency of the animal. The present study was designed to explore the changes in hematological and biochemical parameters in cyclic and PPA Ongole cattle.

\section{Materials and Methods}

\section{Experimental animals}

The present study was carried out at a local farm in Tanuku, West Godavari $\left(16^{\circ} 45^{\prime}\right.$ 25.8264" North latitude and $81^{\circ}$ 40 47.8632" East Longitude), Andhra Pradesh. A total of 12 multiparous cows between 4-8 years and weighing between 250 to $500 \mathrm{~kg}$ were used in the experiment. The animals were divided in to two groups based on herd record. The cows that had known anestrous for more than 120 days were selected in PPA group $(n=6)$ and animals coming in estrus before 65 days of postpartum were selected in normal cyclic group $(n=6)$ for the study. The experiment was conducted in the month of March, 2020. The animals were maintained as per the standard feeding and management conditions practiced at the farms.

\section{Estimation of haematological and} biochemical parameters

Blood samples were collected by jugular vein puncture from all the animals and used for determination of various hematological variables such as red blood cell count (RBC), total leucocyte count (TLC), differential leukocyte count (DLC) using standard protocols (Schalm et al., 1975), Hb by using Drabkins method (Drabkin, 1994), packed cell volume (PCV) by micro haematocrit method, mean corpuscular volume (MCV), mean corpuscular haemoglobin $(\mathrm{MCH})$, mean corpuscular hemoglobin concentration (MCHC). Other aliquots of blood drawn in to the tubes with clot activators were allowed to clot at ambient temperature for 20 to 30 minutes and then subjected to centrifugation at $3500 \mathrm{rpm}$ for 10 minutes and serum was stored at $-20{ }^{\circ} \mathrm{C}$. The serum was used for estimation of biochemical parameters such as glucose, total protein and cholesterol. The serum glucose was estimated by glucose oxidase (GOD/POD) method (Barham and Trinder, 1972), total plasma proteins by Biuret method (Doumas et al., 1971), and cholesterol by phenol amino antipyrine method (Richmond, 1973). The average mean values of the two groups were compared using unpaired t-test (Snedecor and Cochran, 1994). The whole data was analyzed using computerized software programme SPSS Ver.20.0.

\section{Results and Discussion}

Hematology and biochemical profiles are commonly used as indicators of health status of the animals and for the diagnosis of various livestock diseases (Cetin et al., 2009). Postpartum anoestrous is one common disorder that negatively affects reproductive efficiency in cattle and buffaloes. As a general rule any deviation from normal physiology would reflect hematological and 
biochemical parameters. The existing research evidences an alteration in hematobiochemical profile in PPA animals. Thus a detailed examination of hemato-biochemical profile would help us understand the pathophysiology of underlying disease/ disorder and adopt strategies for improvement of health and production. The mean RBC, $\mathrm{Hb}$, and PCV observed in the present study was significantly $(\mathrm{p}<0.05)$ lower in PPA group compared to control (Table 1). Similar findings were reported in Buffaloes where $\mathrm{RBC}, \mathrm{Hb}$ and $\mathrm{PCV}$ were significantly lower in PPA animals compared to cyclic animals (Ali et al., 2012; Kumar et al., 2015; Ghani et al., 2017; Saikiran et al., 2020). The low Hb concentration in anestrous cows indicates long term protein deficiency which influences tissue oxygenation of the reproductive tract and reflects as irregular cyclicity (Ramakrishna, 1997). Also, lower $\mathrm{Hb}$ in blood is responsible for reduced oxygen transport to the vital tissues, that causes reduced oxidation of nutrients, as a result of which the entire cellular metabolism in gonadal cells is affected (Swenson and Reece, 1993). A decreased PCV generally means red blood cell loss from any variety of reasons like cell destruction, blood loss, and failure of bone marrow production. An increased PCV generally indicates dehydration or an abnormal increase in red blood cell production (Kalsotra et al., 2016). Lower $\mathrm{Hb}$ and PCV are indicative of anemia in anestrous cows. Although the importance of $\mathrm{Hb}$ has not been directly implicated in disorders of reproduction, but still decrease in $\mathrm{Hb}$ value is indicative of certain systemic disorders which indirectly might affect the reproductive organs functioning. In the present study, both the $\mathrm{Hb}$ and PCV were lower in anestrous cows which may be attributed to above mentioned reasons. No significant difference ( $p>0.05)$ was found between PPA and control group for $\mathrm{MCV}, \mathrm{MCH}$, and MCHC (Table 1) and these hematological parameters might not be indicators as these are secondary indices derived from the primary parameters. No significant difference $(p>0.05)$ was found between PPA and control group for WBC concentration, lymphocyte and monocyte percent (Table 1). The non-significant change in lymphocyte and monocyte count indicates that the body defence mechanism was not compromised and that the reproductive tract is free from infections.

The serum glucose was significantly $(\mathrm{p}<0.05)$ higher in control compared to PPA cows (Table 2). The present findings were in accordance with the report of Saikiran et al., (2020) with low glucose values in PPA buffaloes. Singh et al., (2007) observed that plasma glucose was not a metabolic regulator responsible for initiation of ovarian cyclicity. However, the hypoglycemic state would reduce the hypothalamic-hypophyseal-ovarian axis signal transmission leading to anestrus condition. Significantly lower glucose in PPA might be attributed to lactation stress where there is increased glucose utilization for milk production (Saikiran et al., 2020). The total protein concentration in control animals was found to be significantly $(\mathrm{p}<0.05)$ higher than PPA group (Table 2). Our results were in accordance with Vohra et al., (1995), Tandle et al., (1997), Arosh et al., (1998), Kavani et al., (2005), Modi et al., (2017), whereas Singh et al., (2007) and Kumar et al., (2009) found contradictory results that the normal cyclic animals had a significantly lower concentration of serum total protein as compared to anoestrus cows. The variation could be due to differences in breeds, environment and level of nutrition (Ahmed et al., 2004). Low levels of total proteins might cause deficiency of certain amino acids required for gonadotropins synthesis (Vohra et al., 1995). In the present study deficiency of total proteins might have affected the biosynthesis of gonadotropins and gonadal hormones in acyclic cows. The serum total 
cholesterol was significantly $(\mathrm{p}<0.05)$ higher in control compared to PPA cows (Table 2). Our results were in agreement to Jayachandran et al., (2013) and Saikiran et al., (2020) who reported significantly higher plasma cholesterol in cyclic than anoestrus bovines. The changes in plasma cholesterol levels were negatively associated with gonadal steroidogenesis in cattle (Ghani et al., 2017). As the cholesterol is the precursor of sex steroids, estradiol and progesterone, the low cholesterol concentration would negatively affect the ovarian activity and may induce PPA in animals.

Table.1 Mean \pm SE values of hematogical parameters in control and PPA Ongole cows $(\mathrm{n}=6)$

\begin{tabular}{|c|c|c|c|}
\hline SNO & PARAMETER & CONTROL $(\mathbf{N}=6)$ & PPA(N=6) \\
\hline $\mathbf{1}$ & RBC $\left(\times 10^{12} / \mathrm{L}\right)$ & $6.96^{\mathrm{a}} \pm 0.36$ & $4.67^{\mathrm{b}} \pm 0.26$ \\
\hline $\mathbf{2}$ & HGB $(\mathrm{g} / \mathrm{dl})$ & $11.18^{\mathrm{a}} \pm 0.86$ & $7.95^{\mathrm{b}} \pm 0.14$ \\
\hline $\mathbf{3}$ & HCT $(\%)$ & $31.92^{\mathrm{a}} \pm 0.71$ & $23.35^{\mathrm{a}} \pm 0.49$ \\
\hline $\mathbf{4}$ & MCV $(\mathrm{fl})$ & $46.27^{\mathrm{a}} \pm 1.81$ & $50.54^{\mathrm{a}} \pm 1.86$ \\
\hline $\mathbf{5}$ & MCH $(\mathrm{pg})$ & $16.01^{\mathrm{a}} \pm 0.71$ & $17.35^{\mathrm{a}} \pm 1.19$ \\
\hline $\mathbf{6}$ & MCHC $(\mathrm{g} / \mathrm{dl})$ & $35.00^{\mathrm{a}} \pm 0.24$ & $34.1^{\mathrm{a}} \pm 0.11$ \\
\hline $\mathbf{7}$ & WBC $\left(\times 10^{9} / \mathrm{L}\right)$ & $7.57^{\mathrm{a}} \pm 0.85$ & $7.13^{\mathrm{a}} \pm 0.29$ \\
\hline $\mathbf{8}$ & LYMPOCYTE $\left(\times 10^{9} / \mathrm{L}\right)$ & $4.50^{\mathrm{a}} \pm 0.47$ & $5.70^{\mathrm{a}} \pm 0.32$ \\
\hline $\mathbf{9}$ & MONOCYTE $\left(\times 10^{9} / \mathrm{L}\right)$ & $0.57^{\mathrm{a}} \pm 0.15$ & $0.52^{\mathrm{a}} \pm 0.09$ \\
\hline
\end{tabular}

Means with different superscript $(\mathrm{a}, \mathrm{b})$ differ significantly $(\mathrm{P}<0.05)$

Table.2 Mean \pm SE values of biochemical parameters in control and PPA Ongole cows $(n=6)$

\begin{tabular}{|l|l|l|l|}
\hline SNO & PARAMETER & CONTROL $(\mathbf{N}=6)$ & PPA(N=6) \\
\hline $\mathbf{1}$ & GLUCOSE $(\mathrm{mg} / \mathrm{dl})$ & $63.59^{\mathrm{a}} \pm 1.74$ & $50.14^{\mathrm{b}} \pm 1.04$ \\
\hline $\mathbf{2}$ & TOTAL PROTEIN $(\mathrm{g} / \mathrm{dl})$ & $7.93^{\mathrm{a}} \pm 0.05$ & $6.00^{\mathrm{b}} \pm 0.14$ \\
\hline $\mathbf{3}$ & CHOLESTEROL $(\mathrm{mg} / \mathrm{dl})$ & $153.87^{\mathrm{a}} \pm 3.44$ & $97.80^{\mathrm{b}} \pm 9.30$ \\
\hline
\end{tabular}

Means with different superscript $(\mathrm{a}, \mathrm{b})$ differ significantly $(\mathrm{P}<0.05)$

In conclusion, anestrous is one of the commonly occurring impaired reproductive condition. It is therefore important to understand the physiological status through hemato-biochemical parameters estimation which could help us to adopt strategies for improvement of reproductive function. From the present study, we observed significantly, lower $\mathrm{RBC}, \mathrm{Hb}, \mathrm{PCV}$, glucose, total protein and cholesterol, in PPA compared to control animals. Low RBC, $\mathrm{Hb}$ and PCV is suggestive of reduced oxygen delivery to reproductive tissues. Low glucose is suggestive of hypoglycemia and lowered total protein and cholesterol is indicative of lack of precursors for protein and steroid hormone synthesis. Hence, it may be concluded that PPA significantly reflects marked changes hemato-biochemical parameters. These changes could be used as markers of PPA. Since PPA is associated with production and income, addressing this issue is of paramount importance. Thus early diagnosis by complete hemato-biochemical and hormonal assay would help us to identify PPA animal in advance and adopt strategies to improve the reproductive efficiency. 


\section{Acknowledgements}

The authors are greatly thankful to Sri Venkateswara Veterinary University. We thankfully recognize the accessibility of the necessary facilities provided by NTR College of Veterinary Sciences, Gannavaram, is duly acknowledged.

\section{Conflict of Interest}

The authors declare that there is no any conflict of interest for this manuscript.

\section{References}

Ali, R., and Shukla, S.P. 2012. Haematobiochemical changes in post-partum anoestrus buffaloes during low breeding season. Researcher. 4 (9):55-58.

Ahmad, I., Lodhi, L. A., Qureshi, Z. I., and Younis, M. 2004. Studies on blood glucose, total proteins, urea and cholesterol levels in cyclic, non-cyclic and endometritic crossbred cows. Pakistan Veterinary Journal. 24(2): 9294.

Arosh, A. J., Kathiresan, D., Devanathan, T. G., Rajasundaram, R. C., and Rajasekaran, J. 1998. Blood biochemical profile in normal cyclical and anoestrus cows. Indian journal of animal sciences. 68(11):1154-1156.

Barham, D., and Trinder, P. 1972. An improved colour reagent for the determination of blood glucose by the oxidase system. Analyst. 97(1151):142145.

Butani, M.G., Dhami, A.J. and Kumar, R. 2011. Comparative blood profile of progesterone, metabolites and minerals in anestrus, sub-estrus, repeat breeding and normal cyclic buffaloes. Indian $\mathrm{J}$. Field Vets. 7(2): 20-24

Cetin, N., Bekyurek, T., Cetin, E. 2009. Effect of sex, pregnancy and season on some haematological and biochemical blood values in Angora rabbits. Scand. J. Lab. Anim. Sci. 36 (2): 155-162.

Doumas, B. T., Watson, W. A., and Biggs, H. G. 1971. Albumin standards and the measurement of serum albumin with bromcresol green. Clinicachimicaacta. 31(1): 87-96.

Drabkin, D.L. 1944. Photometry and spectrophotometry. Chicago: Year Book Medical Publication.

Ghani, M.U., Ahmad, I., Ahmad, N., Ijaz, N., Mehfooz, A. 2017. Hematology, serum total cholesterol and thyroid hormone concentrations in cyclic and acyclic Nili-Ravi buffaloes. Pakistan Veterinary Journal. 37 (1): 31-34.

Jani, R. G., Prajapati, B. R., \& Dave, M. R. 1995. Haematological and biochemical changes in normal fertile and infertile Surti buffaloes. Indian Journal of Animal Sciences (India)

Jayachandran, S., K Nanjappan, K., Muralidharan, J., Selvaraj, P., and Manoharan., A. 2013. Blood biochemical and mineral status in cyclic and postpartum anestrus buffaloes. Int $\mathbf{J}$ Food Agric Vet Sci. 3: 93-97.

Kalsotra, R., U. Sharma, S. Kumar, S. Kumar and Hussain, K. 2016. Studies on changes in hemato-biochemical and enzymatic profile in postpartum anestrus murrah buffaloes with hormonal protocols. Buffalo Bulletin 35: 112-116.

Kavani, F.S., Khasatiya, C.T., Sthankl, D.J., Thakur, D.B., Dhami, A.J. and Panchal, M.T. 2005. Studies on postpartum biochemical and hormonal profile of fertile and infertile estrous cycles in Surti buffaloes. Indian J. Anim. Reprod. 26(1): 1-6.

Khan, H.M., Bhakat, M., Mohanty, T.K., Pathbanda, T.K. 2014. Influence of vitamin $\mathrm{E}$, macro and micro minerals on reproductive performance of cattle and 
buffalo-a review. Agricultural Reviews. 35(2):113-121. Doi: 10.5958/09760741.2014.00088.9

Kumar Rajesh, Butani, M.G., Dhami, A.J., Kavani, F.S. and Shah, R.G. 2009. Effects of different therapies on fertility and serum progesterone, metabolites and minerals profile in repeat breeding CB cows. Indian J. Field Vets. 5(2):1-8.

Kumar, S., \& and Sharma, M. G. 1991. Level of hemoglobin and certain serum biochemical-constituents in rural cows during fertile and non-fertile estrus. Indian Veterinary Journal. 68(4): 361364.

Kumar, S., Balhara, A.K., Kumar, R., Kumar, N., Buragohain, L., Baro, D et al., 2015. Hemato-biochemical and hormonal profiles in post-partum water buffaloes (Bubalus bubalis). Veterinary world. 8(4):512. Doi: 10.14202/ vetworld.2015.512-517.

Kumar, S., M. C. Sharma, S. K. Dwivedi, S. K. Agrawal and Pathak, N. M. 1991. A note on clinico-haematological changes in normal cyclic, anoestrus and repeat breeding buffaloes. Indian Journal of Animal Reproduction. 12: 92-93.

Kumar, S., Raju, B. M. K., Ramarao, C. A., and Ramilan, T. 2015. Sensitivity of livestock production to climatic variability under Indian drylands and future perspective. Current Agriculture Research Journal. 3(02):142-149.

Malik, R. K., P. Singh, I. J. Singh, R. K. Sharma, S. K. Phulia, R. K. Tuli and Chandolia, R. K. 2011. Ovarian response and fertility of Ovsynchtreated postpartum anestrus Murrah buffaloes. Buffaloes Bulletin. 30: 272276.

Modi, L.C., Suthar, B.N., Sharma, V.K., Nakhashi, H.C., Panchasara, H.S. and Modi, F. 2017. Comparative biochemical profile of blood serum and estrual mucus in normal and repeat breeding Kankrej cow. Indian Journal of Animal Health. 56(1): 53-58.

Montiel, F., and Ahuja, C. 2005. Body condition and suckling as factors influencing the duration of postpartum anestrus in cattle: a review. Animal Reproduction Science. 85(1-2):1-26.

Nishi, S.A., Sarder, M.J., Islam, M.H., Josim Uddin, M., Sharmin S. 2018. Managemental Factors Influencing Anestrus Problems in Dairy Cows. J Vaccines vaccin. 9(393):2.

Perera, BMAO. 2011. Reproductive cycles of buffalo. Animal Reproduction Science. $124 \quad$ (3, 4):194-199. doi.org/10.1016/j.anireprosci.2010.08.0 22

Pouilly, F., Viel, J.F., Mialot, J.P., Sanaa, M., Humblot, P., Ducrot, C., Grimard, B. 1994. Risk factors for post-partum anoestrus in Charolais beef cows in France. Preventive Veterinary Medicine. 18(4): 305-14.

Ramakrishna, K. V. 1997. Comparative studies on certain bio-chemical constituents of anoestrus cross-bred Jersey rural cows. Indian Journal of Animal Reproduction. 18: 33-35.

Richmond, W. 1973. Determination of cholesterol by enzymatic method. Clin.Chem. 19:1350-56.

Schalm, O.W., Jain, N.C., and Carroll, E.J. 1975. Veterinary Hematology: Lea \& Febiger.

Saikiran, B.V.S., Vasantha, S.K.I., Nikhil K.T.J., Lavanya, S., Chandra Prasad, B., Rama Goury M and Srinivasa Prasad CH. 2020. Assessment of hemato biochemical, mineral and oxidative changes in postpartum anestrous (true anoestrous) Murrah buffaloes. International Journal of chemical studies 8(6) : 29-33.

Singh, C. P., Saxena, A., Shiv Prasad, and Prasad, J.K. 2007. Comparative studies on metabolic profile of anestrus and 
normal cyclic Haryana cows. Indian Journal of Animal Reproduction. 28(1):42-45.

Snedecor, G.W. and Cochran, W.G. 1994. Statistical Methods. $8^{\text {th }}$ edn. Iowa State University Press, Ames, Iowa, USA.

Swenson, J. M., and Reece, O. W. 1993. Duke's Physiology of Domestic Animals, $11^{\text {th }}$ edition Cornell University Press, New York, USA pp : 351.

Tandle, M.K., Amanullah, M., Honnappagol, S.S., Kartikesh, S.M., Jagjiwanram, S. and Sonwane, S.D. 1997. Serum on cholesterol, total proteins, phosphorus and calcium levels in estrous and anestrus non-descript cows. Indian Journal of Animal Reproduction. 18(1): 44-45.

Vohra, S.C., Dindorkar, C.V. and Kaikini, A.S. 1995. Studies on blood serum levels of certain biochemical constituents in normal cycling and anestrous crossbred cows. Indian Journal of Animal Reproduction. 16(2): 85-87.

Wang, J., Chen, C. C., and Osaki, S. 1983. Optimization of the phosphorus-UV reagent. In Clinical Chemistry. 29(6): 1255-1255.

\section{How to cite this article:}

Rama Goury, M., B.V.S. Saikiran, S.K.I. Vasantha, Nikhil Kumar Tej and Srinivasa Prasad, C.H. 2021. Assessment of Haematological and Biochemical Changes in Postpartum Anoestrous Ongole Cattle of Andhra Pradesh. Int.J.Curr.Microbiol.App.Sci. 10(01): 1773-1779. doi: https://doi.org/10.20546/ijcmas.2021.1001.207 